\title{
COMPARATIVE QUALITY EVALUATION OF BREAD PRODUCED FROM WHEAT-ADUH (DIOSCOREA BULBIFERA) COMPOSITE FLOUR
}

\author{
C.N. Nwachukwu ${ }^{1}$ and J.C. Nwosu ${ }^{2}$ \\ Department of Food Science and Technology, Imo State University, Owerri. \\ Department of Home Economics, School of Secondary Education (Vocational), Federal College \\ of Education (Technical), Omoku, Rivers State. \\ *Corresponding author: kizacar2003@gmail.com; +2348038747878.
}

\begin{abstract}
Bread were produced from six flour samples comprising of $100 \%$ wheat flour (sample A) (control) and five samples obtained from blends of wheat flour and aduh (Dioscorea bulbifera) flour at different ratio 95:5 (sample B), 90:10 (sample C), 85:15 (sample D), 80:20 (Sample E), and 75:25 (sample $F$ ). The bread samples were analyzed for proximate composition and sensory scores. Results showed that there were significant differences $(p<0.05)$ between values obtained for proximate composition ranging from $8.07 \%$ to $8.79 \%, 12.38 \%$ to $12.49 \%, 2.35 \%$ to $2.45 \%$, $22.15 \%$ to $24.57 \%$ and $52.82 \%$ to $54.10 \%$ for protein, fat, fibre, ash, moisture and carbohydrate contents respectively. Data obtained from the anti - nutrient content of the bread samples ranged from $0.004 \%$ to $0.042 \%, 0.030 \%$ to $1.124 \%, 0.072 \%$ to $0.094 \%$ and $0.033 \%$ to $0.107 \%$ for tannin, phytate, oxalate and saponin. The results showed that tannin, oxalate and saponin contents increased with increase in the substitution of wheat flour with aduh (Dioscorea bulbifera) flour. The result also showed that 5-10\% substitutions of the wheat flour with aduh (Dioscorea bulbifera) flour were mostly accepted by the members of the panelist. The results obtained also suggested that bread made from the different flour blends of wheat flour and aduh (Dioscorea bulbifera) flour can compare favourably with the conventional bread made from $100 \%$ wheat flour in quality.
\end{abstract}

Key words: Aduh, Bread, Proximate Composition, Anti-Nutrients

https://dx.doi.org/10.4314/jafs.v16i2.3

\section{INTRODUCTION}

Bread is an important staple food in both developed and undeveloped countries, known for its taste, aroma and texture. It is a staple food prepared by baking dough of flour and water (Osuji, 2006). Salt, fat and yeast are common ingredients in addition to a wide range of other ingredients namely; milk, egg, sugar, spice, fruits, vegetables, nuts and seeds (Encyclopedia Britannica, 2006).

Wheat flour of both hard and soft wheat classes have been the major ingredients of leavened bread for many years because of its functional proteins (Abdelghafor et al., 2011). Breads along Journal of the Faculty of Agriculture and Veterinary Medicine, Imo State University Owerri website: www ajol.info 
with cereals, legumes, bran, rice and pasta make up the foundation of a healthy diet. These foods are rich sources of energy (carbohydrate), provide some protein, are economical and are naturally rich in iron and fat. Breads made with enriched flours also provide thiamin, riboflavin, niacin and iron.

Dioscorea bulbifera commonly known as air potato, aerial yam, cheeky yam belong to the family of dioscoreaceae. It is a vigorous climber plant reaching up to 6 meters or more with smooth stems ranging from 1 to $8 \mathrm{~mm}$ in diameter, twinning in clockwise direction. It is found in both Africa and Asia, with slight differences between those found in the two places (Bhandari et al., 2005). The leaves and bulbils of Dioscorea bulbifera are used for traditional medicine in many areas. It has been used as a folk remedy to treat conjunctivitis, diarrhea and dysentery, among other ailments (Kayodeet al., 2017).

The yam species produces aerial starch bulbils which are usually grey or brown in color with white or yellow mucilaginous flesh. Apart from starch, the bulbils contain other chemical elements such as protein, fat, fibres and minerals (Abara et al., 2000). Dioscorea bulbifera is cultivated at the beginning of raining season from March to June. Bulbils are formed at the leaves armpit. In African races of the plant these bulbils are sharply angled, while those of Asian races are spherical to ellipsoid. The ground tuber arises from a swelling of the young stem and enlarged rapidly as storage organs. Both bulbils and tubers are edible although tubers are usually hard and biter. Bulbils are usually harvested after senescence and death of the plant. At that period of vegetable cycle of the plant, the bulbils fall down. For farmers, the fall of the bulbils is only one indication of maturity in the Dioscorea bulbifera.

Dioscorea bulbifera is a good source of calories and minerals such as iron, calcium and phosphorous (Abara et al., 2000). The moisture, ash, protein, fiber and carbohydrate content of yam vary among species and between cultivars. Dioscorea bulbifera is cultivated for their bulbils which are consumed once they are cooked like potatoes and water with oil and other local ingredient or by boiling.

Dioscorea bulbifera is one of the most common and widespread specie of yam found in the tropical regions of the world. Due to poor information on bread baking potentials of Dioscorea bulbifera, its utilization in the bakery industries is been overlooked. This study therefore is aimed to evaluate the quality of bread produced from wheat- aduh (Dioscorea bulbifera) composite flour.

\section{MATERIALS AND METHODS}

\section{Sample Procurement and Preparation}

Aduh (Dioscorea bulbifera), wheat flour and other baking ingredient were procured from Ekeukwu market, Owerri, Imo State while baking equipment were obtained from Food Science and Technology Laboratory, Imo State University.

Aduh (Dioscorea bulbifera) was sorted, washed, peeled, parboiled and oven dried. The dried samples were milled using a hammer mill and sieved, the resulting aduh (Dioscorea bulbifera) flour were packaged in an air tight container pending usage.

\section{Journal of the Faculty of Agriculture and Veterinary Medicine, Imo State University Owerri} website: www ajol.info 


\section{Formulation of Sample}

The flour used for the bread production is from blends of wheat flour and aduh (Dioscorea bulbifera) flour. The composite flour samples were obtained by blending the wheat- aduh (Dioscorea bulbifera) flour in the ratio of (100:0, 95:5; 90:10; 85:15, 80:20 and 75:25). The $100 \%$ wheat flour served as the control sample.

\section{ANALYSES}

\section{Proximate Analysis of the Bread Samples}

Proximate composition, namely; moisture, crudeprotein, crude fibre, ash, total lipids and carbohydrate contents of the bread samples were measured according to thestandard methods of AOAC (2010).

\section{Anti- Nutrient Analysis of the Bread Samples}

The anti nutrient compositions of the bread samples which include tannin, phytate, oxalate and saponin contents were determined using prescribed methods of Onwuka (2005).

\section{Sensory Evaluation}

Samples were subjected to sensory evaluation using twenty panelists randomly selected from the student and staff of the University community. The samples were coded and presented to the panelists in clean transparent plastic plates at room temperature $\left(27 \pm 2{ }^{\circ} \mathrm{C}\right)$ in individual booths with adequate florescent lights. Sample presented to the panelists was at random and one at a time. Water was provided for mouth wash in between evaluations. Panelists rated the products for overall acceptability and sensory attributes of appearance, aroma, taste and texture. A 9-point hedonic scale was used for rating.

\section{Statistical Analyses}

Data was analyzed using one-way analysis of variance (ANOVA). Values of $p<0.05$ were considered statistically significant. All data were expressed as the mean \pm SD of three observations.

\section{RESULTS AND DISCUSSION}

\section{Proximate Composition of Bread Samples}

The result of proximate composition of the bread samples produced from wheat and aduh (Dioscorea bulbifera)flour composite blend is shown in Table1.

It was observed that there was no significant $(\mathrm{p}<0.05)$ difference in the moisture content of the bread samples although there was increase in moisture content level of the bread with increase in the level of substitution of wheat flour with aduh (Dioscorea bulbifera) flour. The result is in agreement with the work of Adebowale et al. (2009) on influence of sweet potato flour diastatic activity on rheology, baking and sensory characteristics of wheat - sweet potato composite bread. The increase in moisture level with increase in the level of substitution might serve as an indication of decreasing storage stability since high moisture content may affect the storage

\section{Journal of the Faculty of Agriculture and Veterinary Medicine, Imo State University Owerri} website: www ajol.info 
ability and product quality. Moisture content is an index of water activity and it is used as a measure of stability and susceptibility to microbial contamination (Sanni et al. 2006).

The protein content of the bread samples decreased significantly $(\mathrm{p}<0.05)$ with increase in the inclusion of the aduh (Dioscorea bulbifera) flour to the wheat flour. The result obtained from this present study is in agreement with the findings of Aider et al. (2012). This decrease in protein content could be attributed to the low protein content of aduh (Dioscorea bulbifera) flour. The fat content of the bread samples slightly decreased as the proportion of aduh (Dioscorea bulbifera) flour increased although there was no significant $(\mathrm{p}<0.05)$ difference between the bread samples. This finding is similar to that of Dhingra and Jood (2002) on quality evaluation of bread from wheat - water yam (Dioscorea alata) composite flour blends. The fibre content of the bread samples increased slightly as the proportion of aduh (Dioscorea bulbifera) flour inclusion to the wheat flour increased.

The ash content of the bread samples significantly $(\mathrm{p}<0.05)$ increase as the proportion of aduh (Dioscorea bulbifera) flour increased. Ash content of a food is an index of mineral content. Aduh (Dioscorea bulbifera) have been found to be important in human food source. It is economically important world wide as a food crop (Langeland, 2003). The carbohydrate content of the bread samples significantly $(\mathrm{p}<0.05)$ increased as the proportion of aduh (Dioscorea bulbifera) flour increased. This is attributed to higher carbohydrate content of aduh (Dioscorea bulbifera) flour compared to wheat flour. Similar results have been reported by Elijah (2014). This implies that bread produced from composite flour would be a good source of high energy and nutrient dense food for consumers.

\section{Anti- Nutrient Composition of Bread Samples}

The anti-nutrient content of the bread sample is shown in Table 2.

The tannin, phytate, oxalate and saponin contents of the bread samples slightly increased with increase in aduh (Dioscorea bulbifera) flour in the composite blend although none exceeded the acceptable safe limit. This shows that the bread samples are safe for consumption since their anti-nutrient contents are lower than the lethal doses $(<2.5 \mathrm{mg} / 100 \mathrm{~g})$.

\section{Sensory Scores of Bread Samples}

The mean sensory scores of the bread samples produced from wheat- aduh (Dioscorea bulbifera) flour are shown in Table 3.

The result from sensory evaluation shows that bread can be produced from wheat - aduh (Dioscorea bulbifera) composite flour blend. The result shows that the bread samples produced from composite blend with the incorporation of aduh (Dioscorea bulbifera) flour not more than $10 \%$ in the wheat - aduh (Dioscorea bulbifera) flour composite blend could be used to produce a bread with acceptable organoleptic quality. The control sample (sample A) recording higher sensory scores for all the parameters analysed could be attributed to the fact that the panelists were more accustomed to $100 \%$ wheat bread (Sample A) rather than the newly formulated bread samples (Samples B, C, D, E and F). 


\section{CONCLUSION}

The use of locally available foodstuff to formulate and fortify foods agrees with the guideline and criteria set out by the federal Ministry of Health in Nigeria (FMOH, 1999), calling for the use of available foodstuff in various communities in the country to prepare food for children and adult, so as to ensure availability and affordability.

Bread was successfully produced from composite blends of wheat and aduh (Dioscorea bulbifera) flour. The results of this research show clearly that bread produced from wheat - aduh (Dioscorea bulbifera) composite flour produced bread with improved nutritional composition compared to bread produced from $100 \%$ wheat flour. Anti-nutrient composition results also showed that bread produced from wheat - aduh (Dioscorea bulbifera) flour composite blend are safe and fit for consumption. This research has revealed the great potential of aduh (Dioscorea bulbifera) flour in food processing.

In general, the incorporation of aduh (Dioscorea bulbifera) flour not more than $10 \%$ in the wheat - aduh (Dioscorea bulbifera) flour composite blend could be used to produce a safe bread with improved nutrient composition and acceptable organoleptic quality. The use of locally available crops such as aduh (Dioscorea bulbifera) in right substitution to wheat flour should be encouraged as they are cheap, available and nutritious. 


\section{REFERENCES}

Abara, A.E., Udosen, E.O., and Eka, O.U. (2003). Moisture Content and Polyphenol Oxidase Activity of Growing, Dioscorea bulbifera as indicators of tuber maturation. Global Journal of Pure Applied Science,9: 113-115.

Adebowale, A.R.A, Sanni, S.A. and Oladapo, F.O. (2009). Chemical, Functional and Sensory Properties of Instant Yam-Breadfruit Flour. Nigerian Food Journal, 26: 2-12.

Aider, M., Sirois-Gosselin, M. and Boye, J.I. (2012). Pea, Lentil and Chickpea Protein Application in Bread Making. Journal of Food Research, 1(4).

AOAC (2010). Association of official analytical chemists (18 $8^{\text {th }}$ ed.). Washington D. C. USA.

Bhandari, M.R. and Kawabeta, J. (2005). Bitterness and Toxicity in Wild Yam (Dioscorea spp.) Tubers of the Nepal. Plant foods for the human nutrition, 60 (3): 129-135.

Dhingra, S. and Jood, S. (2002). Effect of Supplementation on Physicochemical, Sensory and Nutritional Charateristics of Bread. Nutrition and Health; 16: 479- 488.

Elijah, I.O. (2014). The Prospects and Challenges of Cassava Inclusion in Wheat Bread Policy in Nigeria. International Journal of Science, Technology and Societ, 2:6-17.

Encyclopedia Britannica, (2006). Bread Britannica Concise Encyclopedia Britannica Inc. www.britannicaencyclopedia.com. Accessed 12/3/2018.

Federal Ministry of Health (FMOH) (1999). Food-based Dietary Guidelines for Nigeria. Nutrition Division, Abuja.

Igbabul, B., Num, G. and Amove, J. (2014). Quality evaluation of composite bread produced from wheat, maize and orange fleshed sweet potato flours. American Journal of Food Science and Technology; 2 (4): 109- 115.

Kayode1, R. M. O., Buhari, O. J., Otutu, L. O., Ajibola, T. B., Oyeyinka, S.A., Opaleke, D. O and Akeem, S. A. (2017). Physicochemical properties of processed aerial yam (Dioscorea bulbifera) and sensory properties of paste (Amala) prepared with cassava flour. The Journal of Agricultural Sciences; 12( 2): 84-94.

Langeland, K. A. (2003). Natural area weeds: Air potato (Dioscorea bulbifera). IFAS Publication SS AGR 164. Florida Cooperative Extension Service, Agronomy Department, University of Florida.

Onwuka, G.T. (2005). Food Analysis and Instrumentation Theory and Practices. Naphtali prints, Lagos Nigeria.

Osuji, C.M. (2006). Importance and Use of Additives in Bread Making. A paper Presented at a Training Works Shop in the use of Cassava/wheat Composite Flour and non biomate additives for making bread and other confectionaries.

Sanni, L. O., Adebowale, A. A., and Tafa, S. O. (2006). Proximate, Functional, Pasting and Sensory Qualities of Instant Yam Flour. A Paper Presented at the 14 ISTRC Symposium, Central Tuber Crops the Research Institute, Trivandrum, Kerala State, India. 


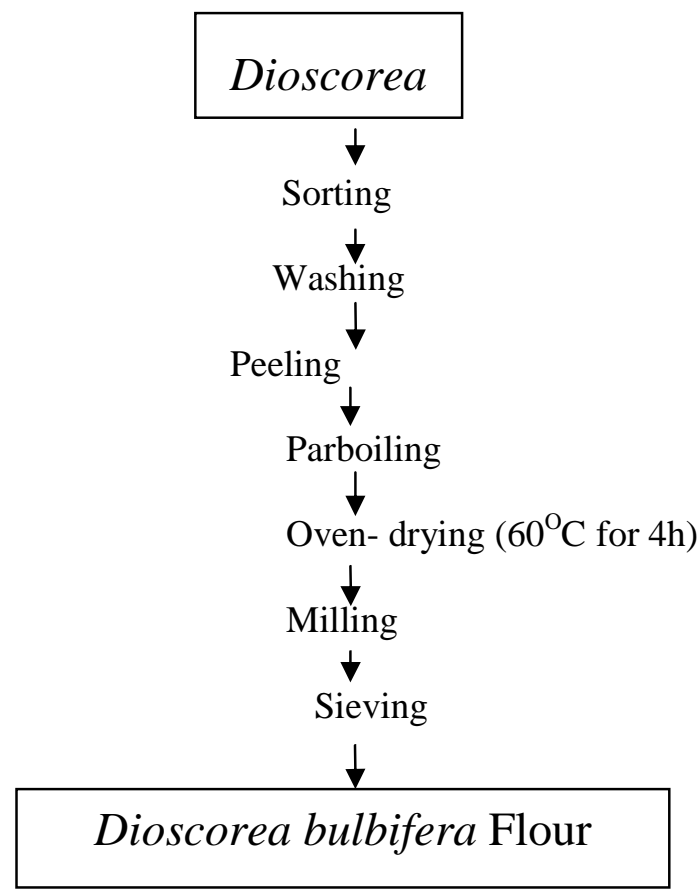

Fig: 1 Preparation ofDioscorea bulbifera Flour

Table 1: $\quad$ Recipe for Wheat -Aduh Composite Flour Bread Production

\begin{tabular}{ll}
\hline Ingredients & Quantities \\
\hline Flour & $100 \mathrm{~g}$ \\
Yeast & $2.5 \mathrm{~g}$ \\
Sugar & $2 \mathrm{~g}$ \\
Salt & $2.5 \mathrm{~g}$ \\
Fat & $2 \mathrm{~g}$ \\
Water & $65 \mathrm{ml}$ \\
\hline
\end{tabular}

Igbabul et al. (2014)

Journal of the Faculty of Agriculture and Veterinary Medicine, Imo State University Owerri website: www ajol.info 


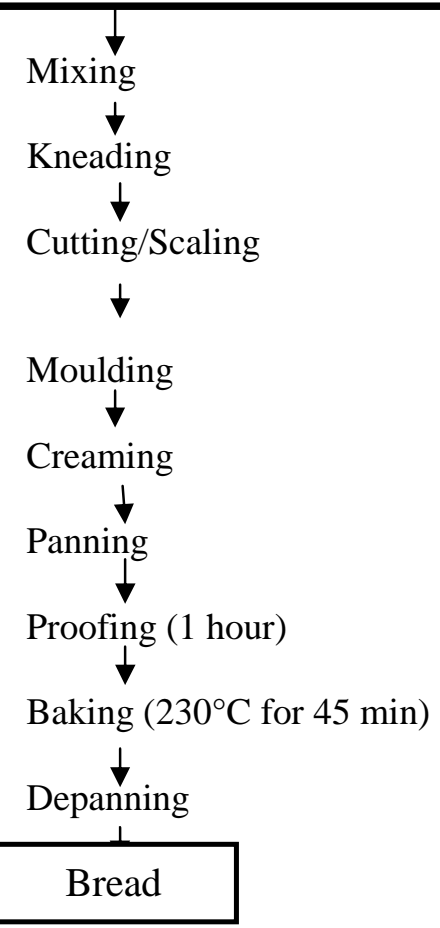

Fig 2: Flow Chart for Bread Production

Table 1: Proximate Composition of Bread Sample

\begin{tabular}{lccccccc}
\hline Parameters (\%) & $\mathbf{A}$ & $\mathbf{B}$ & $\mathbf{C}$ & $\mathbf{D}$ & $\mathbf{E}$ & $\mathbf{F}$ & LSD \\
\hline Moisture & $22.15^{\mathrm{a}} \pm 0.24$ & $22.20^{\mathrm{a}} \pm 0.03$ & $22.21^{\mathrm{a}} \pm 0.02$ & $22.40^{\mathrm{a}} \pm 0.40$ & $22.60^{\mathrm{a}} \pm 0.51$ & $24.57^{\mathrm{a}} \pm 4.58$ & 5.32 \\
Protein & $8.79^{\mathrm{a}} \pm 0.27$ & $8.49^{\mathrm{ab}} \pm 0.1$ & $8.21^{\mathrm{bc}} \pm 0.06$ & $8.19^{\mathrm{bc}} \pm 0.05$ & $8.11^{\mathrm{c}} \pm 0.02$ & $8.07^{\mathrm{c}} \pm 0.02$ & 0.36 \\
Fat & $12.49^{\mathrm{a}} \pm 0.15$ & $2.49^{\mathrm{a}} \pm 0.12$ & $12.49^{\mathrm{a}} \pm 0.12$ & $12.42^{\mathrm{a}} \pm 0.02$ & $12.41^{\mathrm{a}} \pm 0.03$ & $12.38^{\mathrm{a}} \pm 0.03$ & 0.26 \\
Fibre & $1.39^{\mathrm{d}} \pm 0.02$ & $1.45^{\mathrm{cd}} \pm 0.01$ & $1.49^{\mathrm{bc}} \pm 0.03$ & $1.52^{\mathrm{abc}} \pm 0.02$ & $1.55^{\mathrm{ab}} \pm 0.02$ & $1.58^{\mathrm{a}} \pm 0.04$ & 0.08 \\
Ash & $2.35^{\mathrm{c}} \pm 0.01$ & $2.37^{\mathrm{c}} \pm 0.01$ & $2.41^{\mathrm{b}} \pm 0.02$ & $2.43^{\mathrm{ab}} \pm 0.01$ & $2.45^{\mathrm{a}} \pm 0.01$ & $2.45^{\mathrm{a}} \pm 0.01$ & 0.04 \\
Carbohydrate & $52.82^{\mathrm{a}} \pm 0.50$ & $52.99^{\mathrm{a}} \pm 0.11$ & $53.20^{\mathrm{a}} \pm 0.13$ & $53.27^{\mathrm{a}} \pm 0.46$ & $53.40^{\mathrm{a}} \pm 0.47$ & $54.10^{\mathrm{a}} \pm 4.58$ & 5.20
\end{tabular}

Mean in the same row with the same superscript are not significantly different at $p<0.05$. The means were separated using least significant difference ( LDS)

\section{KEY}
A $\quad 100 \%$ wheat flour bread (Control)
B $\quad 95 \%$ wheat flour $+5 \%$ aduh (Dioscoreabulbifera) flour bread
C $\quad 90 \%$ wheat flour $+10 \%$ aduh (Dioscoreabulbifera) flour bread
D $\quad 85 \%$ wheat flour $+15 \%$ aduh (Dioscorea bulbifera) flour bread

Journal of the Faculty of Agriculture and Veterinary Medicine, Imo State University Owerri website: www ajol.info 
Journal of Agriculture and Food Sciences

Volume 16 Number 2, October $2018 \quad$ pp 26 - 35.

E $\quad 80 \%$ wheat flour $+20 \%$ aduh (Dioscorea bulbifera) flour bread

F $\quad 75 \%$ wheat flour $+25 \%$ aduh (Dioscorea bulbifera) flour bread

Table 2: Anti-Nutrient Composition of Bread Sample

\begin{tabular}{cccccccc}
\hline Parameters & A & B & C & D & E & F & LSD (mg/100g) \\
\hline \multirow{2}{*}{ Tannin } & Nil & Nil & $0.004^{\mathrm{d}} \pm 0.001$ & $0.014^{\mathrm{c}} \pm 0.001$ & $0.032^{\mathrm{b}} \pm 0.003$ & $0.042^{\mathrm{a}} \pm 0.001$ & 0.04 \\
Phytate & $0.030^{\mathrm{a}} \pm 0.001$ & $0.056^{\mathrm{a}} \pm 0.004$ & $0.444^{\mathrm{a}} \pm 0.583$ & $0.794^{\mathrm{a}} \pm 0.574$ & $0.805^{\mathrm{a}} \pm 0.574$ & $1.124^{\mathrm{a}} \pm 0.003$ & 1.23 \\
Oxalate & $0.072^{\mathrm{b}} \pm 0.006$ & $0.075^{\mathrm{ab}} \pm 0.006$ & $0.75^{\mathrm{ab}} \pm 0.006$ & $0.083^{\mathrm{ab}} \pm 0.013$ & $0.086^{\mathrm{ab}} \pm 0.00$ & $0.094^{\mathrm{a}} \pm 0.009$ & 0.02 \\
Saponin & Nil & Nil & Nil & $0.033^{\mathrm{c}} \pm 0.009$ & $0.060^{\mathrm{b}} \pm 0.000$ & $0.107^{\mathrm{a}} \pm 0.012$ & 0.02 \\
\hline
\end{tabular}

Mean in the same row with the same superscript are not significantly different at $p<0.05$. The means were separated using least significant difference ( LDS)

\section{$\underline{\text { KEY }}$}

A $\quad 100 \%$ wheat flour bread (Control)

B $\quad 95 \%$ wheat flour $+5 \%$ aduh (Dioscoreabulbifera) flour bread

C $\quad 90 \%$ wheat flour $+10 \%$ aduh (Dioscoreabulbifera) flour bread

D $\quad 85 \%$ wheat flour $+15 \%$ aduh (Dioscorea bulbifera) flour bread

E $\quad 80 \%$ wheat flour $+20 \%$ aduh (Dioscorea bulbifera) flour bread

F $\quad 75 \%$ wheat flour $+25 \%$ aduh (Dioscorea bulbifera) flour bread

Table 3: Sensory Scores of Bread Sample

\begin{tabular}{lccccccc}
\hline Parameters & $\mathbf{A}$ & $\mathbf{B}$ & $\mathbf{C}$ & $\mathbf{D}$ & $\mathbf{E}$ & $\mathbf{F}$ & LSD \\
\hline Aroma & $7.97^{\mathrm{a}}$ & $5.67^{\mathrm{b}}$ & $5.63^{\mathrm{b}}$ & $5.50^{\mathrm{b}}$ & $5.43^{\mathrm{b}}$ & $5.27^{\mathrm{b}}$ & 0.92 \\
Colour & $7.97^{\mathrm{a}}$ & $5.70^{\mathrm{bc}}$ & $6.33^{\mathrm{b}}$ & $5.47^{\mathrm{c}}$ & $5.93^{\mathrm{bc}}$ & $5.10^{\mathrm{c}}$ & 0.85 \\
Taste & $7.97^{\mathrm{a}}$ & $6.13^{\mathrm{b}}$ & $6.13^{\mathrm{b}}$ & $6.07^{\mathrm{b}}$ & $5.23^{\mathrm{bc}}$ & $5.10^{\mathrm{c}}$ & 0.93 \\
Texture & $7.93^{\mathrm{a}}$ & $6.10^{\mathrm{bc}}$ & $6.13^{\mathrm{b}}$ & $5.83^{\mathrm{bc}}$ & $6.47^{\mathrm{b}}$ & $5.30^{\mathrm{c}}$ & 0.99 \\
General & $8.17^{\mathrm{a}}$ & $6.20^{\mathrm{b}}$ & $6.17^{\mathrm{b}}$ & $5.87^{\mathrm{bc}}$ & $5.53^{\mathrm{bc}}$ & $5.27^{\mathrm{c}}$ & 0.89 \\
Acceptability & & & & & & & \\
\hline
\end{tabular}

Mean in the same row with the same superscript are not significantly different at $p<0.05$. The means were separated using least significant difference (LDS)

Journal of the Faculty of Agriculture and Veterinary Medicine, Imo State University Owerri website: $w$ ww ajol.info 


\section{$\underline{\text { KEY }}$}
A $\quad 100 \%$ wheat flour bread (Control)
B $\quad 95 \%$ wheat flour $+5 \%$ aduh (Dioscoreabulbifera) flour bread
C $\quad 90 \%$ wheat flour $+10 \%$ aduh ( Dioscoreabulbifera) flour bread
D $\quad 85 \%$ wheat flour $+15 \%$ aduh (Dioscorea bulbifera) flour bread
E $\quad 80 \%$ wheat flour $+20 \%$ aduh (Dioscorea bulbifera) flour bread
F $\quad 75 \%$ wheat flour $+25 \%$ aduh (Dioscorea bulbifera) flour bread 